\title{
Job satisfaction of nurses in a local health unit: determinants of satisfaction
}

Satisfação profissional dos enfermeiros numa unidade local de saúde: determinantes da satisfação

Satisfacción profesional de los enfermeros en una unidad sanitaria local: determinantes de la satisfacción

Cláudia Isabel Neves Pacheco da Silva*(D); Teresa Maria Ferreira dos Santos Potra** (D)

\begin{abstract}
Background: Job satisfaction (JS) is associated with quality in organizations, so its evaluation is essential to create support policies and structures.

Objective: To analyze the job satisfaction of nurses in a local health unit.

Methodology: Descriptive, analytical study with observational and transversal design, of the quantitative type. The Professional Satisfaction Assessment Instrument (PSAI) was used for data collection.

Results: Sample $(n=218)$, predominantly female $(84.6 \%)$, with a mean age of 33 years, presenting a total JS of $66.6 \%$. The most satisfied have between 21-30 years of service. However, in terms of salary, the youngest (22-34 years), single, with a shorter period of service ( $\leq 5$ years), nurse category, and who provide 36-45 hours of care per week, are the most satisfied.

Conclusion: Nurses have a regular JS, which is related to age, family situation, professional category, workload, and, mainly, to the years of service.
\end{abstract}

Keywords: job satisfaction; nurses; nursing

\section{Resumo}

Enquadramento: A satisfação profissional (SP) está associada à qualidade das organizaçóes, pelo que a sua avaliação é essencial para a criação de políticas e estruturas de suporte.

Objetivo: Analisar a satisfação profissional dos enfermeiros numa unidade local de saúde.

Metodologia: Estudo descritivo, analítico, com desenho observacional e transversal, do tipo quantitativo. Utilizou-se o Instrumento de Avaliação da Satisfação Profissional para a colheita de dados.

Resultados: Amostra $(n=218)$, predominantemente feminina $(84,6 \%)$, com a idade média de 33 anos, apresentando uma SP total de 66,6\%. Os mais satisfeitos têm entre 21-30 anos de serviço. Contudo, face ao vencimento auferido, são os mais jovens (22-34 anos), solteiros, com menos tempo de serviço ( $\leq 5$ anos), categoria de enfermeiro, que prestam $36-45 \mathrm{~h}$ de cuidados por semana, que apresentam maior satisfação.

Conclusáo: Os enfermeiros apresentam uma SP regular, que se relaciona com a idade, situação familiar, categoria profissional, carga horária e, principalmente, com os anos de serviço.

Palavras-chave: satisfação no emprego; enfermeiros; enfermagem

*MSc., RN, Local Health Unit of the Alentejo Coast, Basic Emergency Services of Odemira, 7540-230, Santiago do Cacém, Portugal [claudiasilva312@gmail.com].(1) https:// orcid.org/0000-0002-4885-6962. Contribution to the article: bibliographical research, research outline, data collection and statistical analysis, discussion of results, and writing of the article. Address for correspondence: Rua Maria Madalena Falcão n. ${ }^{\circ} 23$, 7630-127, Odemira, Portugal.

7630-127, Odemira, Portugal.
**Ph.D., Coordinating Professor, Nursing School of Lisbon, 1700-063, Lisbon, Portugal [tsantos@esel.pt]. (1) https://orcid.org/0000-0002-5344-0136. Contribution to the article: bibliographical research, research outline, discussion of results, and writing of the article.

\section{Resumen}

Marco contextual: La satisfacción profesional (SP) está asociada a la calidad de las organizaciones, por lo que su evaluación es esencial para la creación de políticas y estructuras de apoyo.

Objetivo: Analizar la satisfacción profesional de los enfermeros en una unidad sanitaria local.

Metodología: Estudio descriptivo, analítico, con diseño observacional y transversal, de tipo cuantitativo. Se utilizó el Instrumento de Evaluación de la Satisfacción Profesional para la recogida de datos.

Resultados: Muestra $(n=218)$ predominantemente femenina $(84,6 \%)$, con una edad media de 33 ańos, que presenta una SP total del 66,6\%. Los más satisfechos tienen entre 21 y 30 ańos de servicio. Sin embargo, en relación con el salario percibido, son los más jóvenes (22-34 años), los solteros, los que cuentan con menos tiempo de servicio ( $\leq 5$ años), la categoría de enfermero, los que prestan 36-45h de cuidados por semana, los que presentan mayor satisfacción.

Conclusión: Los enfermeros presentan una SP regular, que se relaciona con la edad, la situación familiar, la categoría profesional, la carga horaria y, principalmente, con los años de servicio.

Palabras clave: satisfacción en el trabajo; enfermeros; enfermería 


\section{Introduction}

Job satisfaction (JS) is a behavioral organization variable that is crucial in improving organizational functioning, potentially affecting performance and management and, consequently, the quality of services provided to the population (Mendes, 2014). Therefore, in order to define support structures and organizational policies that promote this variable, it is imperative that we understand it. The economic and financial crisis that began in 2008 required a reduction in expenses, which led to a lack of investment in health services. During this period, nurses saw work conditions deteriorate, which were also reflected in the pay, precisely due to the freeze on career progression and pay scales that were not adjusted for more than 10 years. An aggravating factor is that the professional career currently does not differentiate between different training levels, creating inequalities between nurses. Not hiring more nurses during this period led to an increase in work overload, resulting in a decrease of human resources; in 2015, Portugal had 6.3 nurses per 1000 inhabitants, a value that is much lower than the average from the Organization for Economic Co-operation and Development, which is 9.0 (Ferreira, Fernandez, \& Anes, 2017; Organization for Economic Co-operation and Development, 2017). Keeping in mind what has been said, this study had the following objectives: evaluate the degree of JS among nurses of a local health unit (LHU) in the southern region of Portugal and identify the relationship between sociodemographic and organizational variables and job satisfaction.

\section{Background}

JS is the result of a response to work, related to productivity, organizational commitment, the intention to leave (the current job and/or the profession), burnout, work-family conflict and the quality of care (Cunha, Cunha, Rego, Neves, \& Cabral-Cardoso, 2016; Silva \& Potra, 2017). Leaders play an important role in promoting this variable, by creating work environments that facilitate access to information, resources and training and development opportunities, serving as mediating mechanisms for providing quality care (Koy, Yunibhand, Angsuroch, \& Fisher, 2015; Laschinger, Heather, \& Fida, 2015). Thus, the understanding of what influences JS and its effect becomes a work tool for health organizations, enabling the designing of strategies for improving and/ or maintaining JS, with the goal of controlling its results (Silva \& Potra, 2017). In addition to structural support and management practices as determinant factors for employee JS, Spector (2012) classifies the factors that influence it, keeping in mind its origin: a personal cause, if associated with the individual, like age, gender, education, marital status and service time; an organizational cause, like scheduling, the work itself or professional training. In this respect, the study by Ferreira et al. (2017) showed that nurses who were most satisfied were the youngest, least educated, with a time of service under 10 years and with lower salary, contradicting the study by Moura, Brás, Anes, and Ferreira (2016), which concluded that the most satisfied nurses are male, in older age tiers, married, with children, and specialist nurses. Thus, the need arises to evaluate nurse JS at a LHU, identifying the determinant sociodemographic and organizational variables.

\section{Research questions}

This research is guided by the following questions: What is the level of job satisfaction of nurses at a LHU? Can LHU nurses' level of job satisfaction be related to the sociodemographic and organizational variables?

\section{Methodology}

A descriptive, analytical study, with observational and transversal design, of the quantitative type, was undertaken at a LHU in the southern region of Portugal. A questionnaire was used, the Professional Satisfaction Assessment Instrument (PSAI), developed by the Centre of Health Studies and Research at the University of Coimbra, consisting of 28 questions divided into five groups. The first focuses on organizational factors: hourly workload and years of service in the health sector. The second, third, and fourth enable the evaluation of JS regarding three fundamental aspects using 
the following scales: Workplace Quality (WQ), Quality of Care (QC) and Continuous Quality Improvement (CQI), where the sum of all corre- spond to overall JS. These scales are divided into subscales and/or facets and items that characterize them, as shown in Table 1.

Table 1

Scales, subscales, facets, and items included in the PSAI

\begin{tabular}{|c|c|c|c|}
\hline Scales & Subscales & Facets & Items \\
\hline \multirow{6}{*}{ WQ } & \multirow{2}{*}{$\begin{array}{l}\text { Human } \\
\text { Resources } \\
\text { Policy }\end{array}$} & $\begin{array}{l}\text { Management } \\
\text { Bodies }\end{array}$ & $\begin{array}{l}\text { "recognition by management bodies"; "communication, complaints } \\
\text { and objections"; "planning activities" }\end{array}$ \\
\hline & & $\begin{array}{l}\text { Human } \\
\text { Resources }\end{array}$ & $\begin{array}{l}\text { "continuity of staff"; "hierarchical ratios"; "number of professionals"; } \\
\text { "teamwork"; "communication" }\end{array}$ \\
\hline & \multirow[b]{2}{*}{ Moral } & State of Mind & "his/hers"; "others" \\
\hline & & Coordinator & $\begin{array}{l}\text { "opening"; "reasonableness"; "innovation"; "freedom"; "positive } \\
\text { attitude"; "constructive attitude"; "investment in quality"; "support"; } \\
\text { "expectations"; "knowledge"; "circulation of information" }\end{array}$ \\
\hline & \multirow{2}{*}{$\begin{array}{l}\text { Techno- } \\
\text { logical and } \\
\text { Financial } \\
\text { Resources }\end{array}$} & Wages & $\begin{array}{l}\text { "in accordance with one's responsibility," "one's experience"; and } \\
\text { "one's performance" }\end{array}$ \\
\hline & & $\begin{array}{l}\text { Workplace } \\
\text { Equipment }\end{array}$ & "cleanliness"; "safety"; "organization of space and equipment" \\
\hline QC & & & $\begin{array}{l}\text { "service"; "coordination of care"; "health professionals' abilities"; } \\
\text { "sensitivity"; "conditions of the facilities"; "information"; and "cost } \\
\text { of care" }\end{array}$ \\
\hline CQI & & & $\begin{array}{l}\text { "quality improvement"; "well the first time"; "understanding of qual- } \\
\text { ity"; "workplace environment"; "reduce waste"; "sharing of ideas"; } \\
\text { "pride in the profession"; and "expectations of quality" }\end{array}$ \\
\hline
\end{tabular}

Note. CQI = Continuous Quality Improvement; WQ = Workplace Quality; QC = Quality care.

The answers given are on a 5-point Likert scale, where: 1 = poor $; 2$ = average $; 3=$ good $; 4=$ very good $; 5=$ excellent. Each item on this scale corresponds to a percentage scale from 0 to $100 \%$, according to the following criteria: poor - $0 \%$; average - $50 \%$; good - $70 \%$; very good - $90 \%$; excellent $-100 \%$. The value obtained varies between 0 and $100 \%$, where the higher the value, the higher the JS. Group five combines the questions of the sociodemographic framework: gender; age; family situation; family household; number of children; education; and professional category. The PSAI is very trustworthy, showing Cronbach values found in previous studies, in the majority of situations, above 0.90 . In this study, there were Cronbach values over 0.88 and 0.90 in all scales, subscales, and facets. The gathering of data took place in January 2017, with questionnaires delivered on paper to the head nurse/responsible for each unit or participants.

The participants themselves placed the com- pleted questionnaires in sealed boxes. The target population corresponded to all nurses (344). However, considering the active human resources at the time of the data collection, 311 questionnaires were delivered (accessible population). The nurses completed 218 questionnaires, corresponding to the final sample. The statistical treatment of the data was completed using the IBM SPSS Statistics, version 24.0 program for Windows. Descriptive and comparative statistical measures were used like Student's $t$-test $(t)$ and One-Way ANOVA $(F)$ statistical test, since, according to Marôco (2007), for large samples, these are robust enough even when the distribution of the variable is not the normal type. Sheffés post hoc test was used to determine which groups there were the most statistically significant differences.

Regarding the rejection area, the significance level $p=0.05$ was considered, with a confidence interval at $95 \%$. The ethical and legal procedures were taken into consideration, spe- 
cifically, informed consent, confidentiality and data privacy. The questionnaires were delivered with a presentation letter, containing the objectives of the study and participants were not required to identify themselves. Filling out of sociodemographic data was optional, and only the researchers had access to that information. The author requested authorization to use the scale, which was granted. The Ethics Committee gave a positive opinion, and the LHU Board of Directors authorized the completion of the study.

\section{Results}

\section{Sociodemographic and professional char- acterization}

Two hundred eighteen nurses participated in the study, a response rate of $70.1 \%$. The sample consists of 84.7 female professionals, with a mean age of 33 years. Regarding the family situation, $64 \%$ of the nurses are married or live with a partner, $28 \%$ are single, and $8 \%$ are separated/divorced. The majority is part of a family household of three or four members $(56 \%)$, followed by two members (41\%) and $3 \%$ with five or more members. More than half of the participants (59\%) have one or two children, 39\% do not have children, $2 \%$ have three or four. Regarding education, 58\% have a licentiate, $23 \%$ have a master's and $17 \%$ a doctorate, $2 \%$ a bachelor's degree. In terms of professional category, $90 \%$ are nurses or graduate nurses, $7 \%$ are specialist nurses, and 3\% are head nurses. We found that $39.9 \%$ of the professionals in the sample work in the area of primary healthcare, $57.8 \%$ in hospital care and $2.3 \%$ in continued care. Half of the participants complete 35 hours of care, $36.9 \%$ work 36 to 40 hours, and $8.5 \%$, between 41 and 45 hours. In terms of years of service, $20.3 \%$ have worked up to 5 years, $24.3 \%$ have 6 to 10 years of experience, $29 \%$ between 11 and 20 years, 21\% between 21 and 30 years and $6 \%$ have worked for 31 years or more. The majority of participants does not accumulate duties (81.3\%).

\section{Job satisfaction}

Mean satisfaction within the WQ and QC areas were at an average level, at $61.8 \%$ and $67.8 \%$, respectively, while the CQI showed a mean of good satisfaction (70.4\%). Most participants
(77\%) exhibit satisfaction rated between $a v$ erage and good regarding WQ and $2 \%$ rated it as very good, while $21 \%$ of participants rated their workplace satisfaction as poor (Figure 1). The Human Resources Policy subscale satisfaction mean was $55.6 \%$, corresponding to an average rating. Regarding the facet of Management Bodies, the satisfaction mean is $51.4 \%$ (average), with the highest-rated item being "activity planning" (50\%) and the lowest being "recognition by management" and "communication" (37.9\% each). The Human Resources facet received an average satisfaction rating with a value of $59.20 \%$, with the highest-rated items being "communication" and "teamwork" (63.2\% and 62.4\%, respectively) and the lowest-rated being "number of human resources" (29.5\%). In terms of the Morale subscale, there was a mean satisfaction of $70.8 \%$, rated as good. The State of Mind shows a mean satisfaction of $68.6 \%$ (mean), with both items receiving average ratings (65.2\% e $69.4 \%)$. The Coordinator facet received a mean satisfaction of $71.6 \%$. The items in this facet with the highest satisfaction were "openness" and "freedom" (75.6\% each), and the lowest were "investment in quality," "positive attitude" and "constructive attitude" (59\%, 59\%, and 58.2\%, respectively). The Technology and Financial Resources subscale shows a mean satisfaction of $52.6 \%$, rated as average. The Wages aspect received a mean satisfaction of $22 \%$, where all items were rated as poor (related to experience - 29.5\%; to performance - $17 \%$; responsibilities - $17 \%$ ). Regarding the Workplace and Equipment, the mean satisfaction was $63.0 \%$, rated as average, with the highest-rated item in terms of satisfaction being "cleanliness" $(78.2 \%)$ and the lowest being "equipment" (62.4\%). Also, in the QC dimension, the majority of participants $(82.4 \%)$ demonstrate a job satisfaction rating between average and good, about $8 \%$ as very good, as well as a band of $10 \%$ who rated it as poor (Figure 1). The highest-rated items regarding satisfaction were "ability of professionals" and "sensitivity," having received a classification of $76.2 \%$ and $72.8 \%$, respectively. Within this scope, the lowest value found referred to the item "information" (59.2\%). In terms of CQI, the majority of participants $(74 \%)$ continues to present job satisfaction varying between the classifications of average and good; about 13\% 
classified it as very good, and the band of participants that rates it as poor is about 13\% (Figure $1)$. Among the items that are part of the CQI scale, the one that received the best classification was "pride in the profession," at 76.8\%. The remaining items received similar ratings, varying between $62.4 \%$ and $71.4 \%$. Regarding the subscales/facets that are part of the WQ area, represented in Table 2, participants showed higher satisfaction in the Morale subscale and with its facets of Coordinator (71.6\%) and State of Mind (68.6\%), and a lower degree of satisfaction with the Technological and Financial Resources subscale with its Wages facet, at 22.0\% (Table 2).

\section{Workplace Quality $61.8 \%$}

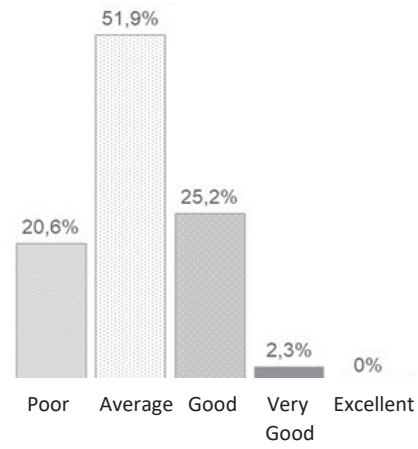

Quality of Care $67.8 \%$

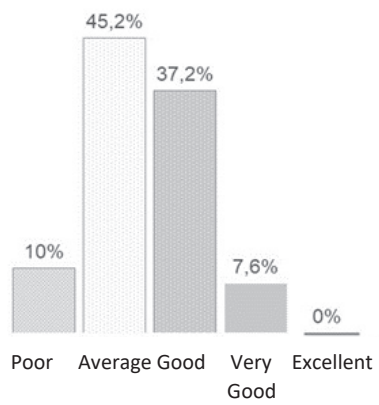

Continuous Quality Improvement $70.4 \%$

Figure 1. Job satisfaction by area.

Table 2

Job satisfaction in the Workplace area by subscales and facets

\begin{tabular}{|c|c|}
\hline Subscales & Facets \\
\hline \multirow{2}{*}{$\begin{array}{l}\text { HRP: } 55.6 \% \\
(M: 2.28 ; S D \pm 0.66)\end{array}$} & Management Bodies - Mean: 51.4\% (M: 2.07; $S D \pm 0.82)$ \\
\hline & Human Resources - Mean: 59.2\% ( $M: 2.46 ; S D \pm 0.74)$ \\
\hline \multirow{2}{*}{$\begin{array}{l}\text { Morale: } 70.8 \% \\
(M: 3.04 ; S D \pm 0.99)\end{array}$} & State of Mind - Mean: $68.6 \%(M: 2.90 ; S D \pm 0.82)$ \\
\hline & Coordinator - Mean: 71.6\% (M: 3.06; $S D \pm 1.09)$ \\
\hline \multirow{2}{*}{$\begin{array}{l}\text { Mean TFR: } 52.6 \% \\
(M: 2.13 ; S D \pm 0.65)\end{array}$} & Wages - Mean: $22.0 \% \quad(M: 1.44: S D \pm 0.67)$ \\
\hline & Workplace Equipment - Mean: $63.0 \%(M: 2.65 ; S D \pm 0.89)$ \\
\hline
\end{tabular}

Note. $S D=$ Standard Deviation; $M=$ Mean; HRP $=$ Human Resources Policy; TFR $=$ Technological and Financial Resources.

Taking the results into account, the mean total satisfaction with a Local Health Unit was $66.6 \%$, rated as average.

Determinants of JS and correlation to sociodemographic and organizational variables Relative to sociodemographic factors, better
JS scores occur among females, though without statistical significance. In regard to age, the differences at the average satisfaction level are statistically significant for the Morale subscales and the Coordinator facets $(p=0.020$ and $p=0.016$, respectively), with the 45 to 54 age group demonstrating greater satisfac- 
tion $(79.9 \%$ and $81.14 \%$, respectively) than the 35 to 44 age group $(65.89 \%$ and $65.56 \%$, respectively). In the State of mind facet, there was also a difference noted at the average satisfaction level $(p=0.036)$, where once again the 45 to 54 age group $(73.03 \%)$ showed greater satisfaction, this time in relation to the group with $\geq 55$ years of age $(53.75 \%)$. For the facet Wages $(p=0.001)$, the groups of 22 to 34 -year-olds $(22.02 \%)$ and of $\geq 55$-year-olds
(45.83\%) show greater satisfaction than the group of 35 to 44 -year-olds (10.33\%). With respect to marital status, there are statistically significant differences in the subscale Technological and Financial Resources and the Wages facet ( $p=0.010$ and $p=0.007$, respectively), with the unmarried group $(56.8 \%$ and $33.9 \%$, respectively) showing greater satisfaction than the married/common law group $(52.5 \%$ and $17.7 \%$, respectively), according to Table 3 .

Table 3

Job satisfaction according to age and family status

\begin{tabular}{|c|c|c|c|c|c|c|c|c|c|c|c|c|c|c|c|c|}
\hline \multirow{3}{*}{ हुँّ } & \multirow{2}{*}{ 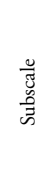 } & \multicolumn{8}{|c|}{ Age } & \multicolumn{7}{|c|}{ Family status } \\
\hline & & \multirow[b]{2}{*}{$\Sigma$} & \multicolumn{3}{|c|}{ Average (\%) } & \multirow[b]{2}{*}{$\begin{array}{c}\geq 55 \\
(4)\end{array}$} & \multicolumn{3}{|c|}{ Test } & \multicolumn{4}{|c|}{ Average (\%) } & \multicolumn{3}{|c|}{ Test } \\
\hline & 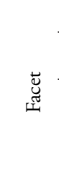 & & $\begin{array}{l}22-34 \\
(1)\end{array}$ & $\begin{array}{l}35-44 \\
(2)\end{array}$ & $\begin{array}{l}45-54 \\
(3)\end{array}$ & & $\mathbf{F}$ & $p$ & Post Hoc & $\Sigma$ & $\begin{array}{c}\text { Unmarried } \\
(1)\end{array}$ & $\begin{array}{c}\text { Married/ } \\
\text { Conmon } \\
\text { Law } \\
(2)\end{array}$ & $\begin{array}{c}\text { Separated } \\
\text { / Divorced } \\
\text { (3) }\end{array}$ & $\mathbf{F}$ & $p$ & $\begin{array}{l}\text { Post } \\
\text { hoc }\end{array}$ \\
\hline & $n$ & 196 & 105 & 50 & 33 & 8 & & & & 201 & 57 & 128 & 16 & & & \\
\hline WQ & & 62.02 & 61.75 & 59.35 & 67.42 & 60.60 & 2.388 & 0.070 & & 61.97 & 62.75 & 61.73 & 61.08 & 0.147 & 0.863 & \\
\hline & HRP & 56.01 & 54.49 & 56.26 & 61.60 & 52.22 & 2.578 & 0.055 & & 55.91 & 55.52 & 55.84 & 57.78 & 0.181 & 0.835 & \\
\hline & MB & 52.22 & 50.29 & 53.40 & 57.88 & 42.19 & 2.210 & 0.088 & & 52.06 & 51.75 & 52.50 & 49.22 & 0.225 & 0.799 & \\
\hline & HR & 59.05 & 57.85 & 58.24 & 64.88 & 56.50 & 1.988 & 0.117 & & 58.98 & 58.79 & 58.41 & 64.25 & 1.075 & 0.343 & \\
\hline & $\mathrm{MO}$ & 71.36 & 71.30 & 65.89 & 79.90 & 71.54 & 3.367 & $0.020^{*}$ & $3>2$ & 71.24 & 71.11 & 71.10 & 67.95 & 0.244 & 0.784 & \\
\hline & $\mathrm{COO}$ & 71.87 & 71.84 & 65.56 & 81.14 & 74.77 & 3.526 & $0.016^{*}$ & $3>2$ & 71.74 & 71.21 & 72.42 & 68.18 & 0.295 & 0.745 & \\
\hline & SM & 68.56 & 68.38 & 68.37 & 73.03 & 53.75 & 2.896 & $0.036^{*}$ & $3>4$ & 68.55 & 70.53 & 67.73 & 68.00 & 0.548 & 0.579 & \\
\hline & TFR & 52.36 & 53.35 & 50.80 & 51.90 & 51.07 & 0.485 & 0.693 & & 52.52 & 56.77 & 50.63 & 52.50 & 4.673 & $0.010^{*}$ & $1>2$ \\
\hline & WAG & 22.02 & 28.41 & 10.33 & 13.64 & 45.83 & 5.916 & $0.001^{*}$ & $1.4>2$ & 22.22 & 33.92 & 17.58 & 17.71 & 5.134 & $0.007^{*}$ & $1>2$ \\
\hline & $\mathrm{WP}+\mathrm{E}$ & 62.53 & 62.33 & 63.30 & 64.24 & 53.13 & 0.888 & 0.449 & & 62.74 & 66.67 & 60.82 & 64.06 & 2.239 & 0.109 & \\
\hline QC & & 68.15 & 66.87 & 68.63 & 69.46 & 76.43 & 1.098 & 0.351 & & 67.97 & 67.30 & 67.87 & 102.68 & 0.376 & 0.687 & \\
\hline CQI & & 70.65 & 69.38 & 69.30 & 75.61 & 75.31 & 1.540 & 0.206 & & 70.50 & 71.38 & 70.61 & 66.56 & 0.541 & 0.583 & \\
\hline
\end{tabular}

Note. $\mathrm{COO}=$ Coordinator; $\mathrm{SM}=$ State of mind; $\mathrm{F}=$ One-Way ANOVA; WP $+\mathrm{E}=$ Workplace and Equipment; $M=$ Mean; CQI = Continuous Quality Improvement; MO = Morality; $\mathrm{n}=$ Number; MB = Management Bodies; HRP $=$ Human Resources Policy; Post Hoc $=$ Sheffés Post Hoc Test; $p=p$ value; HR = Human Resources; TFR = Technological and Financial Resources; WQ = Workplace Quality; QCP = Quality of Care Provision; WAG = Wages; $\Sigma=$ Sum. * Significant at $5 \%$.

In the professional category, the statistically significant differences were identified only in the facet Wages $(p=0.001)$; nurses classified as "nurse" show greater satisfaction (29.85\%) than those in the "registered nurse" category (7.75\%). There were no observed differences with statistical relevance regarding academic degrees (Table 4).

Table 4

Job satisfaction according to the professional category and academic degree

\begin{tabular}{|c|c|c|c|c|c|c|c|c|c|c|c|c|c|c|c|c|c|c|}
\hline \multirow{3}{*}{ नुँ } & \multirow{3}{*}{ 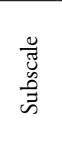 } & \multirow{3}{*}{ 苟 } & \multicolumn{9}{|c|}{ Professional category } & \multicolumn{7}{|c|}{ Academic degree } \\
\hline & & & \multicolumn{6}{|c|}{ Average (\%) } & \multicolumn{3}{|c|}{ Test } & \multicolumn{6}{|c|}{ Average (\%) } & \multirow{2}{*}{$\begin{array}{c}\text { Test } \\
p\end{array}$} \\
\hline & & & $\Sigma$ & $\begin{array}{l}\text { Cheif } \\
\text { (1) }\end{array}$ & $\begin{array}{l}\text { Exper. } \\
\text { (2) }\end{array}$ & $\begin{array}{c}\text { With } \\
\text { Spec. (3) }\end{array}$ & $\begin{array}{l}\text { Grad. } \\
\text { (4) }\end{array}$ & $\begin{array}{l}\text { Nur. } \\
(5)\end{array}$ & F & $p$ & $\begin{array}{l}\text { Post } \\
\text { Hoc }\end{array}$ & $\Sigma$ & $\begin{array}{c}\text { Bach } \\
\text { (1) }\end{array}$ & $\begin{array}{l}\text { Licen } \\
\text { (2) }\end{array}$ & $\begin{array}{l}\text { PG } \\
\text { (3) }\end{array}$ & $\begin{array}{l}\text { Doc } \\
\text { (4) }\end{array}$ & F & \\
\hline & $n$ & & 203 & 6 & 15 & 29 & 43 & 110 & & & & 201 & 3 & 116 & 47 & 35 & & \\
\hline WQ & & & 61.92 & 71.49 & 63.43 & 61.94 & 58.49 & 62.42 & 1.569 & 0.184 & & 61.88 & 61.49 & 61.98 & 60.61 & 63.26 & 0.258 & 0.855 \\
\hline & HRP & & 55.79 & 66.67 & 57.85 & 57.05 & 54.44 & 55.10 & 1.342 & 0.256 & & 55.74 & 53.70 & 55.29 & 55.70 & 57.43 & 0.248 & 0.863 \\
\hline & & MB & 51.85 & 59.17 & 57.33 & 54.66 & 49.42 & 50.77 & 1.235 & 0.297 & & 51.94 & 55.00 & 50.99 & 52.98 & 53.43 & 0.322 & 0.810 \\
\hline & & HR & 58.96 & 72.67 & 58.27 & 58.97 & 58.19 & 58.59 & 1.312 & 0.267 & & 58.78 & 52.67 & 58.63 & 58.17 & 60.63 & 0.370 & 0.775 \\
\hline & $\mathrm{MO}$ & & 71.24 & 86.41 & 72.87 & 70.05 & 66.63 & 72.27 & 1.587 & 0.179 & & 71.21 & 74.62 & 71.42 & 68.99 & 73.21 & 0.344 & 0.793 \\
\hline
\end{tabular}




\begin{tabular}{|c|c|c|c|c|c|c|c|c|c|c|c|c|c|c|c|}
\hline $\mathrm{COO}$ & 1.74 & 7.88 & 72.67 & 70.88 & 66.75 & 72.86 & 1.480 & 0.210 & 71.72 & 77.27 & 71.87 & 69.11 & 74.26 & 0.445 & 0.721 \\
\hline 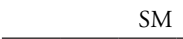 & .51 & 3 & 74.00 & 6553 & 5 & 99 & 83 & 41 & 40 & 0.00 & 68.96 & .30 & 7.43 & 322 & 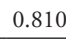 \\
\hline $\mathrm{T}$ & 52.48 & 50.00 & 53.05 & 53.15 & 47.34 & 53.74 & 1.177 & 0.322 & 2.44 & 42.86 & 52.86 & 51.88 & 52.29 & 0.239 & 0.869 \\
\hline AAG & 22.09 & 22.22 & 27.78 & 0.92 & 7.75 & 29.85 & 4.802 & $0.001 * 5$ & 22.31 & 0.00 & 25.29 & 20.21 & 17.14 & 1.110 & 0.346 \\
\hline$+\mathrm{E}$ & 62.71 & 58.33 & 62.00 & 24 & 60.81 & 62.59 & 0.701 & 0.592 & 62.59 & 60.00 & 62.41 & 62.23 & 63.86 & 0.091 & 0.965 \\
\hline 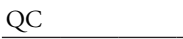 & 67.75 & 82.38 & 69.24 & 0.49 & 64.08 & 67.38 & 2.243 & 0.066 & 67.81 & 59.52 & 67.32 & 67.20 & 71.01 & 0.826 & 0.481 \\
\hline CQI & 70.40 & 82.08 & 71.17 & 70.78 & 70.30 & 69.59 & 0.821 & 0.513 & 70.43 & 71.67 & 70.87 & 67.34 & 73.00 & 0.853 & 0.467 \\
\hline
\end{tabular}

Note Bach = Bachelor; Spec $=$ Specialization; $\mathrm{COO}=$ Coordinator; Doc $=$ Doctorate; $\mathrm{SM}=$ State of mind; Exper.= Expertise; $\mathrm{F}=$ One-Way ANOVA; Licen = License; WP+E = Workplace and Equipment; $M=$ Mean; CQI = Continuous Quality Improvement; $\mathrm{MO}=$ Morality; $n=$ Number; $\mathrm{MB}=$ Management Bodies; $p=p$ value; PG = Postgraduate; HRP = Human Resources Policy; HR = Human Resources; Post Hoc = Sheffés Post Hoc Test; WQ = Workplace Quality; QCP = Quality of Care Provision; TFR = Technological and Financial Resources; WAG = Wages; $\sum=$ Sum. ${ }^{*}$ Significant at $5 \%$.

Considering the relationship between JS and the "weekly workload," differences are found in the Wages facet $(p=0.000)$. Nurses that work between 36 and 45 hours show greater satisfaction $(33.92 \%)$ compared to those who work 35 hours or between 46 and 55 hours. Regarding job satisfaction according to years of service, significant statistical differences appear in the three dimensions of JS (WQ $-p=$ 0.0039; $\mathrm{QCP}-p=0.003$; CQI $-p=0.007$ ). About WQ, nurses with 21 to 30 years of ex- perience show greater satisfaction $(61.89 \%$ and $66 \%$, respectively) in terms of the $\mathrm{Hu}-$ man Resources Policy subscale and Human Resources facet than those nurses with 5 or fewer years of service $(57.28 \%$ and $60.22 \%$, respectively). However, in the Wages facet, the younger nurses ( $\leq 5$ years) are more satisfied $(40.74 \%)$ than those with 21 to 30 years of service $(9.01 \%)$, or even than those with 11 to 20 years (12.09\%; Table 5).

\section{Table 5}

Job satisfaction according to weekly hourly load and years in the health fiel

\begin{tabular}{|c|c|c|c|c|c|c|c|c|c|c|c|c|c|c|c|c|c|}
\hline \multirow{3}{*}{ 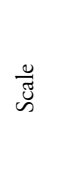 } & \multirow{3}{*}{$\begin{array}{l}\frac{\tilde{J}}{\tilde{J}} \\
\stackrel{\tilde{\omega}}{\vec{B}}\end{array}$} & \multicolumn{7}{|c|}{ Weekly hourly load } & \multicolumn{9}{|c|}{ Years in the health field } \\
\hline & & \multicolumn{4}{|c|}{ Average(\%) } & \multicolumn{3}{|c|}{ Test } & \multicolumn{6}{|c|}{ Average (\%) } & \multicolumn{3}{|c|}{ Test } \\
\hline & & $\Sigma$ & $\begin{array}{c}35 \mathrm{~h} \\
(1)\end{array}$ & $\begin{array}{c}36- \\
45 \mathrm{~h} \\
(2)\end{array}$ & $\begin{array}{c}46-55 \mathrm{~h} \\
\text { (3) }\end{array}$ & F & $p$ & $\begin{array}{l}\text { Post } \\
\text { Hoc }\end{array}$ & $\Sigma$ & $\begin{array}{l}\leq 5 \\
(1)\end{array}$ & $\begin{array}{c}6-10 \\
(2)\end{array}$ & $\begin{array}{c}11-20 \\
\text { (3) }\end{array}$ & $\begin{array}{c}21-30 \\
(4)\end{array}$ & $\begin{array}{c}\geq 31 \\
(5)\end{array}$ & $\mathbf{F}$ & $p$ & $\begin{array}{l}\text { Post } \\
\text { Hoc }\end{array}$ \\
\hline & $n$ & 214 & 107 & 85 & 22 & & & & 177 & 36 & 43 & 51 & 37 & 10 & & & \\
\hline WQ & & 61.77 & 61.80 & 63.28 & 55.62 & 2.811 & 0.062 & & 62.24 & 65.31 & 60.12 & 59.02 & 66.49 & 60.96 & 2.585 & $0.039^{*}$ & - \\
\hline & HRP & 55.75 & 56.73 & 55.85 & 50.42 & 2.033 & 0.134 & & 56.21 & 57.28 & 53.20 & 54.10 & 61.89 & 54.94 & 2.974 & $0.021^{*}$ & $4>2$ \\
\hline & MB & 51.73 & 52.48 & 52.24 & 40.34 & 1.453 & 0.236 & & 52.12 & 53.61 & 47.67 & 50.10 & 56.76 & 53.00 & 1.662 & 0.161 & \\
\hline & HR & 58.98 & 60.13 & 58.57 & 54.76 & 1.261 & 0.286 & & 59.57 & 60.22 & 56.51 & 57.29 & 66.00 & 58.00 & 2.6590 & $0.035^{*}$ & $4>2$ \\
\hline & $\mathrm{MO}$ & 70.92 & 70.91 & 72.89 & 63.43 & 2.051 & 0.131 & & 71.66 & 74.53 & 70.18 & 66.74 & 77.44 & 71.54 & 1.885 & 0.115 & \\
\hline & $\mathrm{COO}$ & 71.36 & 71.39 & 73.51 & 62.89 & 2.148 & 0.119 & & 72.10 & 74.70 & 70.97 & 66.65 & 78.54 & 72.18 & 1.848 & 0.122 & \\
\hline & SM & 68.54 & 68.32 & 69.40 & 66.36 & 0.307 & 0.736 & & 66.26 & 73.61 & 65.81 & 67.80 & 71.35 & 68.00 & 1.464 & 0.215 & \\
\hline & TFR & 52.48 & 51.50 & 54.50 & 48.70 & 1.945 & 0.146 & & 52.65 & 58.49 & 50.33 & 51.12 & 52.16 & 51.14 & 2.838 & $0.026^{*}$ & $=$ \\
\hline & WAG & 21.42 & 13.71 & 33.92 & 10.61 & 11.053 & $0.000^{*}$ & $2>1.3$ & 21.28 & 40.74 & 25.58 & 12.09 & 9.01 & 25.00 & 6.669 & $0.000^{*}$ & $1>3,4$ \\
\hline & $\mathrm{WP}+\mathrm{E}$ & 62.92 & 63.50 & 62.71 & 60.91 & 0.204 & 0.816 & & 63.25 & 67.64 & 57.91 & 63.33 & 66.08 & 59.50 & 2.140 & 0.078 & \\
\hline QC & & 67.63 & 68.96 & 67.72 & 60.75 & 2.781 & 0.064 & & 68.69 & 71.98 & 63.10 & 66.64 & 75.32 & 65.71 & 4.094 & $0.003^{*}$ & $4>2$ \\
\hline CQI & & 70.22 & 69.98 & 71.50 & 66.31 & 0.909 & 0.405 & & 71.19 & 76.32 & 66.51 & 67.99 & 76.55 & 69.17 & 3.679 & $0.007^{*}$ & $4>2$ \\
\hline
\end{tabular}

Note: $\mathrm{COO}=$ Coordinator; $\mathrm{SM}=$ State of mind; F = One-way ANOVA; WP+E = Workplace and Equipment; $M$ = Mean; CQI = Continuous Quality Improvement; MO = Morale; $n=$ Number; MB = Management Bodies; Post $H o c=$ Post Hoc Scheffe Test $p=p$ value; HRP = Human Resources Policy; WQ = Workplace Quality; QCP = Quality of Care Provision; HR = Human Resources; TFR = Technological and Financial Resources; WAG = Wages; $\sum=$ Sum. * Significant at $5 \%$. 


\section{Discussion}

The total JS score obtained was $66.6 \%$, being considered regular. Although this value is lower than that of Azevedo $(2012 ; 71.6 \%)$ or Fonseca $(2014 ; 71.5 \%)$, it is close to the findings in the study by Matos (2012; 67.7\%) which also falls within the level of regular. The JS of the constituent dimensions, QWP (61.6\%), QCP (67.8\%) and CQI (70.4\%), indicated lower scores than those obtained in the studies by Fonseca (2014; WQ: 67.42\%, QCP: $78.28 \%$ and CQI: $80.71 \%)$ and Azevedo (2012; WQ: 65.56\%, QCP: 74.12\% and CQI: $75.37 \%$ ), but they were, however, similar to the crescendo pattern of growth in JS identified along the scales. Thus, nurses find themselves more satisfied with CQI and QCP than with WQ. Exploring the processes that influenced JS, and in particular those that relate to the facets of PSAI, according to Laschinger et al. (2015), authentic leadership, through fundamental empowerment and support of professional practices, can influence the perception of the QCP, and this in turn, strongly contributes to the JS of nurses. The QCP and the CQI are directly related, namely through matters of the work environment, as in support measures for clinical practice and interpersonal relations. Recent studies corroborate the existence of a strong positive connection between the work environment and JS (Koy et al., 2015; You et al., 2013). Satisfaction with CQI constitutes the highest value (70.4\%), reaching a classification of good. The Management Bodies facet obtained the lowest positive average value of satisfaction (51.4\%), followed by Human Resources (59.2\%), contributing as well to the lowest WQ value, this result being therefore backed by the literature. The subscale with the lowest classification is the Human Resources Policy (55.8\%). Among the facets evaluated, State of Mind and Coordinator, making up the subscale Morale, exhibit the highest values for satisfaction among professionals with $68.6 \%$ and $71.6 \%$ respectively, the same being verified by Fonseca (2014; $79.77 \%$ and $80.74 \%$ ), Azevedo (2012; 73.49\% and $73.43 \%)$ and Matos $(2012 ; 72.9 \%$ and $72.1 \%)$. The Coordinator facet garnered the same qualitative mention of good where the items with the best classifications are "openness" and "freedom," portraying an open coordinator with a willingness to communicate, and who trusts in nurses, granting them the freedom to make decisions when necessary. The items that obtained the lowest classification were: "positive attitude," "constructive attitude" and "investment in quality." Although the State of Mind facet exhibits a classification of regular, it is a high value $(68.6 \%)$. Such a case would be expected, since between 2016 and 2017, despite the absence of wage valorization, the largest number of nurse specialists was recorded (23\% of all nurses), revealing commitment and involvement with the performance of duties ( Observatório Português dos Sistemas de Saúde, 2018). Finally, the JS with the subscale Technological and Financial Resources obtained the lowest level of the scale QWP, mainly due to the Wages facet, the only negative value $(22 \%)$, classified as poor. This result is transversal to several studies on job satisfaction for nurses, such as Fonseca (2014), where a value was obtained of $39.01 \%$, of Azevedo (2012; $36.78 \%)$, or Matos (2012; 35.2\%). The Workplace and Equipment facet scored a higher value $(62,8 \%)$ than that recorded in Fonseca (2014; 53.24\%), in Matos (2012; 53.7\%) or Azevedo (2012; 60.9\%). Taking into account the sociodemographic factors studied, contrary to that which was supported in the literature by Spector (2012), no statistically significant differences were observed in JS according to gender or academic degree. In contrast, in relation to age and family status, that correlation was identified. In the age variable, differences are observed in the Coordinator and State of Mind facets, which make up the subscale Morale, and in the Wages facet. In the study by Fonseca (2014), a correlation with age was also observed, albeit in different facets, having only those that relate to Wages in common; but in the studies by Azevedo (2012) and Matos (2012), such was not observed. Nurses between 45-54 years of age show greater satisfaction in relation to Coordinator and State of Mind and consequently, in relation to the subscale Morale, classifying it as good. The literature shows that the reason for greater satisfaction of older workers relates to a modulation in expectations regarding work throughout life, which may lead to a decrease in the level of demands regarding State of Mind and Coordinator 
(Mendes, 2014). When it comes to the State of Mind, the participants with the lowest satisfaction are $\geq 55$ years of age, corresponding to a qualitative assessment of regular. The fact that an age group of $\geq 55$ years of age was included allowed the identification of a small part of the sample $(n=8)$, which although older, has a JS behavior inverse to that which is expected. This finding may be due to the change in retirement age, which began rising in 2007, leading to a shift in what could be the life plan of professionals, at the start and along most of the contribution period (Decreto-Lei no 187/2007 de 10 de maio, 2007). The study by Ferreira et al. (2017) concluded that the nurses most satisfied are the oldest and the youngest, compared to those of intermediate age. A greater satisfaction was observed among the younger age group (22-34 years of age), but only regarding the Wages facet. The intermediate age group (35 to 44 years) shows the lowest satisfaction in that area, as well as in the Coordinator facet. This result may be related to the differences found in JS in regard to family status, since the average age for a first marriage is 32.8 years for men and 31.3 years for women (Instituto Nacional de Estatística, 2017), being precisely those participants in this age range who make up the married/common law group and those least satisfied. Being a group that finds itself overwhelmed with the education of their children, and possibly, with the previous generation, challenges arise in the balance between family and professional life, which may contribute to the lower satisfaction rates. If, on the one hand, they need available capital to manage the education of their children and support the elderly, on the other hand, they also need available time to give support to both generations. This result is congruent with the decrease in the life-work balance indicator that has been observed since 2011, possibly leading to professional dissatisfaction. Individual attention on the part of managers, the offer of diverse work patterns and an increase in the number of professionals may represent strategies to minimize that dissatisfaction (República Portuguesa, 2018; Silva \& Potra, 2017). These facts correlate with the results regarding the professional category since lower satisfaction was observed among the graduate nurses compared to those in the nurse category, since the freeze in the career progression led to the non-valorization of wages in line with professional experience. In relation to the organizational factors, the results line up with the literature, a correlation having been observed with the variable of the length of service and hourly workload. Regarding the latter, wage stagnation justifies the greater satisfaction in light of Wages among nurses who work 36-40 hours, as they earn a higher net amount when compared with those working 35 hours. When compared to those who work 40 or more hours, they also show greater satisfaction since, possibly, due to the tax brackets for Personal Income Tax (IRS), the workto-income ratio may become adverse. The literature establishes very low correlations between JS and wages. However, it shows that the relation assessment is not necessarily due to salary, but to the perceived fairness in comparison to other employees (Spector, 2012). The workload is related to low-to-moderate levels of JS such as those observed in this study and may be exacerbated by the concurrence of shift work (Gouzou, Karanikola, Lemonidou, Papathanassoglou, \& Giannakopoulou, 2015). In the correlation between JS and the length of service variable, statistically significant differences relative to the three dimensions were observed. Besides the reasons presented for the age factor, the older professionals tend to express greater JS for the change in the expectations throughout life, such difference standing out in the Human Resources facet and in the QCP and CQI scales, which showed that the nurses most satisfied have between 21-30 years of service (Mendes, 2014). However, when it comes to wages, nurses with fewer years of experience ( $\leq 5$ years) are the ones who show greater satisfaction when compared with the other age groups. This result may be due to the combination of reasons shown above, insofar as nurses with less length of service may correspond to nurses with the classification of nurse, unmarried, without children and/or smaller households, and thus, fewer family responsibilities. The results of this study show similarities to the studies of Ferreira et al. (2017) and Moura et al. (2016) in that, if, on the one hand, it is the younger nurses and those with shorter lengths of service that are the most satisfied in regard to wages, on the other hand, 
where Morale is concerned, it is older nurses who show greater satisfaction. Contrary to the study of Moura et al. (2016), married nurses show lower satisfaction relative to wages and no relation was observed regarding the professional type or category.

An identified limitation of the study was the extension of the data collection instrument, which hindered the reading and presentation of the results.

\section{Conclusion}

The LHU nurses show a regular JS, are less satisfied with WQ, particularly regarding wages and management bodies, and are more satisfied with aspects of CQI. Nurses feel that wages do not match academic degree, experience, performance or responsibilities assumed and desire an improvement in communication and recognition on the part of management bodies. Also, nurses identify the relationships established with middle management as a source of JS, for openness and willingness to communicate, and it can, therefore, be concluded that these persons are fundamental to maintaining the JS in this LHU. As concerns the provision of care, this is perceived, in its essence, like quality, which may lead to the conclusion that the nature of nursing work can overcome the identified dissatisfaction. JS shows a connection with some sociodemographic and organizational variables. Nurses with length of service (in health; 21 to 30 years) are more satisfied; however, regarding wages, the greatest satisfaction appears among nurses practicing for fewer years ( $\leq 5$ years).

In the same way, older nurses ( $45-54$ years), are also more satisfied in relation to morality and the younger ones (22 - 34 years) regarding wages. The age group between 35 - 44 years stands out for the lowest level of satisfaction in these areas. Satisfaction in light of family status factors, professional category, and the hourly workload is only modulated in terms of wages; the unmarried nurses who give between 36 and 45 hours of care per week are the most satisfied. It must be concluded that, given the diversity of dimensions and determinants of JS, it is crucial to maintain the assessment of JS in health organizations. This study does not allow concluding if the levels of JS obtained can be solely influenced by the studied causes; however, it is acknowledged that they may be due as well to the national austerity plans, given the low satisfaction values obtained on the Human Resources facet, which relate to the number of professionals, hierarchical proportions and continuity of staff. Thus, it is deemed that the current context of financial constraint policies should also be taken into account in the assessment of JS.

Looking at the results obtained, it is recommended that strategies be developed which improve the quality of the workplace, such as the development of effective communication between managing entities and nurses, facilitating the awareness of the challenges experienced by nurses, both in their professional and family lives, so that more personalized strategies may be outlined that minimize the work-family conflict. It is likewise suggested that organizational policies be established which promote the increase in human resources and the improvement of information disclosed to users. At the research level, an analysis of job satisfaction per area of care is suggested, taking into account the specific characteristics of each context, namely, shift work and its relation to other variables such as family-work balance, engagement, productivity, quality, and user satisfaction.

\section{References}

Azevedo, R. O. (2012). Satisfação no trabalho dos profissionais de cuidados de saúde primários (Master's thesis). Universidade Fernando Pessoa, Porto, Portugal.

Cunha, M. P., Cunha, R. C., Rego, A., Neves, P., \& Cabral-Cardoso, C. (2016). Manual de comportamento organizacional e gestão ( $8^{\mathrm{a}} \mathrm{ed}$.). Lisbon, Portugal: Editora RH.

Decreto-Lei no 187/2007 de 10 de Maio. Diário Da República $N^{\circ}$ 90/2007- I Série. Ministério do Trabalho e da Solidariedade Social. Lisboa, Portugal.

Ferreira, C. A., Fernandez, R. F., \& Anes, E. M. (2017). Satisfação profissional dos enfermeiros em unidades hospitalares do norte de Portugal. Revista de Enfermagem Referência, 15(4), 109-120. doi:10.12707/ RIV17043

Fonseca, R. M. (2014). Satisfação profissional nas USF da ARS Centro fatores intrinsecos e extrinsecos do trabalho 
(Master's thesis). Universidade de Coimbra, Portugal. Gouzou, M., Karanikola, M., Lemonidou, C., Papathanassoglou, E., \& Giannakopoulou, M. (2015). Measuring professional satisfaction and nursing workload among nursing staff at a greek coronary care unit. Revista Da Escola de Enfermagem Da USP, 49(spe), 15-21. doi:10.1590/S0080-6234201500000003

Instituto Nacional de Estatística. (2017). Idade média ao primeiro casamento, por sexo. Retrieved from http:// www.pordata.pt/Portugal/Idade+média+ao+primeiro+casamento++ por+sexo-421

Koy, V., Yunibhand, J., Angsuroch, Y., \& Fisher, M. L. (2015). Relationship between nursing care quality, nurse staffing, nurse job satisfaction, nurse practice environment, and burnout: Literature review. International Journal of Research in Medical Sciences, 3(8), 1825-1831. doi:10.18203/2320-6012. ijrms20150288

Laschinger, S., Heather, K., \& Fida, R. (2015). Linking nurses' perceptions of patient care quality to job satisfaction. The Journal of Nursing Administration, 45(5), 276-283. doi:10.1097/NNA.0000000000000198

Marôco, J. (2007). Análise estatística: Com utilização do SPSS. Lisbon, Portugal: Silabo.

Matos, V. M. (2012). Monitorização da satisfação profissional num agrupamento de centros de saúde da regiāo centro. Coimbra, Portugal: University of Coimbra.

Mendes, A. P. (2014). Satisfação profissional dos enfermeiros de cuidados de saúde primários do ACES baixo mondego II (Master's thesis). Escola Superior de Enfermagem de Coimbra, Portugal.
Moura, S., Brás, M., Anes, E., \& Ferreira, C. (2016). Satisfação no trabalho em profissionais de enfermagem. Bragança, Portugal: Instituto Politécnico de Bragança. Retrieved from https://bibliotecadigital.ipb.pt/ handle/10198/13231

Observatório Português dos Sistemas de Saúde. (2018). Relatório primavera 2018: Meio caminho andando. Retrieved from http://opss.pt/relatorios/relatorio-de-primavera-2018/

Organization for Economic Co-operation and Development. (2017). Health at a glance 2017: OECD indicators. Retrieved from http://www.oecd.org/health/ health-systems/health-at-a-glance-19991312.htm

República Portuguesa. (2018). 3 em linha: Programa para a conciliaçâo da vida profissional, pessoal e familiar 2018-2019. Retrieved from https://www.portugal. gov.pt/download-ficheiros/ficheiro.aspx?v=2b472cb7980b-4d69-b744-366020d7e873

Silva, C. N., \& Potra, T. S. (2017). Satisfação profissional dos enfermeiros: Uma revisão scoping. Pensar Enfermagem, 20(2), 33-50. Retrieved from http://pensarenfermagem.esel.pt/files/Artigo3-Paginas33_50.pdf

Spector, P. (2012). Psicologia nas organizaçōes ( $4^{a}$ ed.). São Paulo, Brazil: Saraiva.

You, L. Ming, Aiken, L. H., Sloane, D. M., Liu, K., He, G. Ping, Hu, Y., ... Sermeus, W. (2013). Hospital nursing, care quality, and patient satisfaction: Cross-sectional surveys of nurses and patients in hospitals in China and Europe. International Journal of Nursing Studies, 50(2), 154-161. doi:10.1016/j. ijnurstu.2012.05.003 
